Dewey, D. L. (1954). J. gen. Microbiol. 11, 307-312.

\title{
The Distribution of Diaminopimelic Acid Decarboxylase among some Organisms of the coli-aerogenes Group and certain other Bacteria
}

\author{
BY D. L. DEWEY* \\ Department of Chemical Pathology, University College Hospital \\ Medical School, London, W.C. 1
}

\begin{abstract}
SUMMARY : Diaminopimelic acid decarboxylase was found to be widely distributed among 58 coli-aerogenes organisms. Different strains grown and tested under standard conditions showed great variations in enzyme activity although the amount of diaminopimelic acid in the cell hydrolysates was similar. Except for a higher average activity in Aerobacter aerogenes, there was no correlation between the activity of diaminopimelic acid decarboxylase and the biochemical type of coliform organism. No strain was found that contained diaminopimelic acid decarboxylase in the absence of lysine decarboxylase. The enzyme was also found in a strain of Pseudomonas aeruginosa but not in Proteus vulgaris, Streptococcus faecalis or Bacillus subtilis.
\end{abstract}

Acetone-dried preparations of certain strains of Escherichia coli have been found to contain an enzyme which decarboxylates natural $\alpha$ - $\epsilon$-diaminopimelic acid to $\mathrm{CO}_{2}$ and lysine (Dewey \& Work, 1952a). The amount of this enzyme (diaminopimelic acid decarboxylase) varied from one strain to another and in three strains no activity was detected. Paper chromatographic analysis of the amino acids in acid hydrolysed cells showed that all the strains examined had approximately the same amount of diaminopimelic acid (Work \& Dewey, 1953). Thus there is no obvious correlation between the degree of enzyme activity and the amount of substrate in the cell. The enzyme, with a slightly lower pH optimum, has also been found in a strain of Aerobacter aerogenes (Dewey \& Work, 1952b).

The following survey of the distribution of diaminopimelic acid decarboxylase was undertaken to examine the distribution of the enzyme and to find whether this distribution could be correlated with any other characteristic.

\section{METHODS}

Organisms examined. The strains used were obtained from the Wellcome Bacterial Collection, the M.R.C. Microbiology unit at Cambridge, the National Collection of Type Cultures (NCTC) and the collection kept at this medical school. All strains were tested and classified according to their biochemical reactions, using the system described in The Bacteriological Examination of Water Supplies (1939; see Proom \& Woiwod, 1951).

The culture medium used consisted of: Lab-Lemco (Oxoid) 10 g.; proteose peptone (Difco) $10 \mathrm{~g}$.; $\mathrm{NaCl} 5 \mathrm{~g}$.; glucose $20 \mathrm{~g}$.; distilled water to $1 \mathrm{l}$. and adjusted to $\mathrm{pH} 7: 1 \%(\mathrm{v} / \mathrm{v})$ sterile blood was added when used for growing the streptococcus. The cultures were grown in Roux bottles containing $160 \mathrm{ml}$.

* Present Address: Department of Botany, University College, London, W.C. 1. 
medium; they were mechanically inoculated (Dewey \& Wallace, 1953) and incubated at $37^{\circ}$ for $12.5 \mathrm{hr}$. (the growth time for optimal enzyme activity in Escherichia coli; Dewey, Hoare \& Work, 1954). After incubation the cells were harvested by centrifugation, washed once with water and mixed to a thin paste in water. About 10 vol. cold acetone was added to the paste with rapid stirring and the mixture left at $2^{\circ}$ for $30 \mathrm{~min}$. The cells were filtered on a Buchner funnel, washed with cold acetone and ether, and dried in vacuum.

Substrate. The diaminopimelic acid used had been isolated from hydrolysed cells of Corynebacterium diphtheriae (Work, 1951).

Estimations. The enzyme estimations were made by measuring the $\mathrm{CO}_{2}$ evolved from diaminopimelic acid in a Warburg manometer at $38^{\circ}$ with air as gas phase. Acetone dried cells (40 mg.) suspended in $2 \mathrm{ml} .0 .1 \mathrm{M}$-phosphate buffer ( $\mathrm{pH} \mathrm{6.8)}$ were placed in the main compartment and $0.5 \mathrm{ml} .0 .025 \mathrm{M}$ diaminopimelic acid, dissolved in the same buffer, in the side bulb. The enzyme activity was measured as $Q_{\mathrm{CO}_{2}}=\mu \mathrm{l} . \mathrm{CO}_{2}$ released into the gas phase at $\mathrm{pH} 6 \cdot 8$ / $\mathrm{hr} . / \mathrm{mg}$. acetone-dried cells. No correction for $\mathrm{CO}_{2}$ retention in the buffer was made in the rate determinations. When strains contained an active decarboxylase, $0.2 \mathrm{ml}$. $8 \mathrm{~N}-\mathrm{H}_{2} \mathrm{SO}_{4}$ was tipped in from a second side bulb at the end of the reaction and the total gas change measured. Where the enzyme activity was low and the reaction not near completion after $1.5 \mathrm{hr}$. the enzyme action was stopped by acid tip and the products examined by paper chromatography.

Chromatography. For chromatographic examination of reaction products the contents of Warburg flasks were neutralized with saturated $\mathrm{Ba}(\mathrm{OH})_{2}$ and centrifuged; $40 \mu \mathrm{l}$. of the supernatant fluid was chromatographed on Whatman No. 4 filter paper, with diaminopimelic acid, lysine and cadaverine as markers. Phenol $\left(\mathrm{NH}_{3}\right.$ atmosphere) was the solvent and the spots were developed with ninhydrin.

Amount of diaminopimelic acid in the cells. The approximate diaminopimelic acid content of the organisms was judged from the colour intensities of ninhydrin spots on two-dimensional paper chromatograms of electrodialysed, acid-hydrolysed cells (Work \& Dewey, 1953).

\section{RESULTS}

\section{Lysine decarboxylase}

The lysine formed by the decarboxylation of diaminopimelic acid was itself decarboxylated to cadaverine and $\mathrm{CO}_{2}$ by lysine decarboxylase also present in the acetone-dried cells.

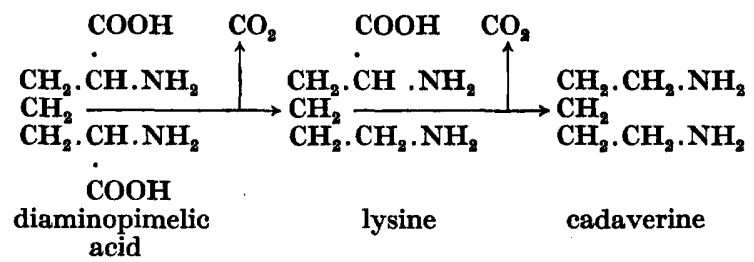

Thus in the overall reaction two molecules of $\mathrm{CO}_{2}$ were produced for each molecule of diaminopimelic acid added. In all the cells with a high enzyme 
activity $80-90 \%$ of this theoretical $\mathrm{CO}_{2}$ was produced. The paper chromatograms also showed that where decarboxylation had taken place the main product was always cadaverine; no appreciable amount of lysine was found, indicating that lysine decarboxylase was the more active enzyme and that diaminopimelic acid decarboxylase was the rate controlling enzyme.

\section{Diaminopimelic acid decarboxylase}

The distribution of diaminopimelic acid decarboxylase among the organisms tested is summarized in Table 1. Many of the strains showed a small gas change $(5 \mu l$.) when left in the Warburg apparatus for several hours, but no lysine or

Table 1. Distribution of diaminopimelic acid decarboxylase among organisms of the coli-aerogenes group

\begin{tabular}{|c|c|c|c|c|c|}
\hline & \multicolumn{4}{|c|}{ No. of strains with $\mathbf{Q}_{\mathrm{CO}_{2}}$} & \multirow[b]{2}{*}{$\begin{array}{c}\text { Presence } \\
\text { of DAP } \\
\text { in cell } \\
\text { hydrolysate }\end{array}$} \\
\hline & $\begin{array}{l}\text { Total no. } \\
\text { of strains }\end{array}$ & $\begin{array}{c}\text { Less } \\
\text { than } \\
0.3\end{array}$ & $\begin{array}{c}\text { Between } \\
0.3 \text { and } \\
\mathbf{2 \cdot 0}\end{array}$ & $\begin{array}{c}\text { Greater } \\
\text { than } \\
\mathbf{2 \cdot 8}\end{array}$ & \\
\hline Escherichia coli type 1 & 17 & 4 & 5 & 8 & + \\
\hline Escherichia coli type 2 & $\mathbf{2}$ & 1 & 1 & $\mathbf{0}$ & nt \\
\hline intermediate type 1 & 12 & 2 & 8 & $\mathbf{2}$ & nt \\
\hline intermediate type 2 & 4 & $\mathbf{0}$ & 2 & $\mathbf{2}$ & nt \\
\hline irregular & 2 & $\mathbf{0}$ & 0 & $\mathbf{2}$ & nt \\
\hline Aerobacter aerogenes type 1 & 19 & $\mathbf{3}$ & 3 & 13 & + \\
\hline Klebsiella pneumoniae & $\mathbf{2}$ & 0 & 1 & 1 & + \\
\hline & 58 & & & & \\
\hline
\end{tabular}

$\mathbf{D A P}=$ diaminopimelic acid $; \mathrm{nt}=$ not tested.

cadaverine was detected when the deproteinized vessel contents were examined by paper chromatography. All strains with a $\mathrm{CO}_{2}$ evolution of less than $12 \mu \mathrm{l} . / \mathrm{hr}$. $\left(Q_{\mathrm{Co}_{2}}\right.$ less than $\left.0 \cdot 3\right)$ are recorded as negative.

The activity of diaminopimelic acid decarboxylase in Aerobacter aerogenes was generally higher than in other organisms examined (Fig. 1). There were, for example, 12 strains of $A$. aerogenes with $Q_{\mathrm{OO}_{2}}$ values greater than 5 as compared with 3 of the strains of Escherichia coli type 1; the average $Q_{\mathrm{CO}_{2}}$ for all the Aerobacter aerogenes strains tested was 6.25 as compared with 2.75 for Escherichia coli type 1. The organism with the highest activity was a strain of Klebsiella pneumoniae with $Q_{\mathrm{OO}_{2}}=24$ but the yield of cells was very small, being $130 \mathrm{mg}$. acetone-dried cells $/ 1$. medium compared with $500 \mathrm{mg}$. $/ 1$. for the next most active organism, a strain of Aerobacter aerogenes with $\mathbf{Q}_{\mathrm{co}_{3}}=22$. A trace of enzyme activity was also found in a strain of Pseudomonas aeruginosa $\left(Q_{\mathrm{Co}_{2}}=1.0\right)$ but no activity could be detected in a strain of Proteus vulgaris or one of Bacillus subtilis.

\section{Diaminopimelic acid content of the cells}

No difference could be detected in the colour strengths of the diaminopimelic acid spots in chromatograms from hydrolysates of seven strains of Escherichia coli, whereas the diaminopimelic acid decarboxylase activity among these seven strains varied from $Q_{\mathrm{oo}}$ values of 0 to 10 . No irregular or intermediate 
types of $E$. coli were examined for the presence of diaminopimelic acid but the amount of this amino acid in hydrolysed Aerobacter aerogenes, Proteus vulgaris, Pseudomonas aeruginosa, Klebsiella pneumoniae and Bacillus subtilis was almost the same as in $\boldsymbol{E}$. coli type 1; Streptococcus faecalis contained neither diaminopimelic acid nor its decarboxylase.

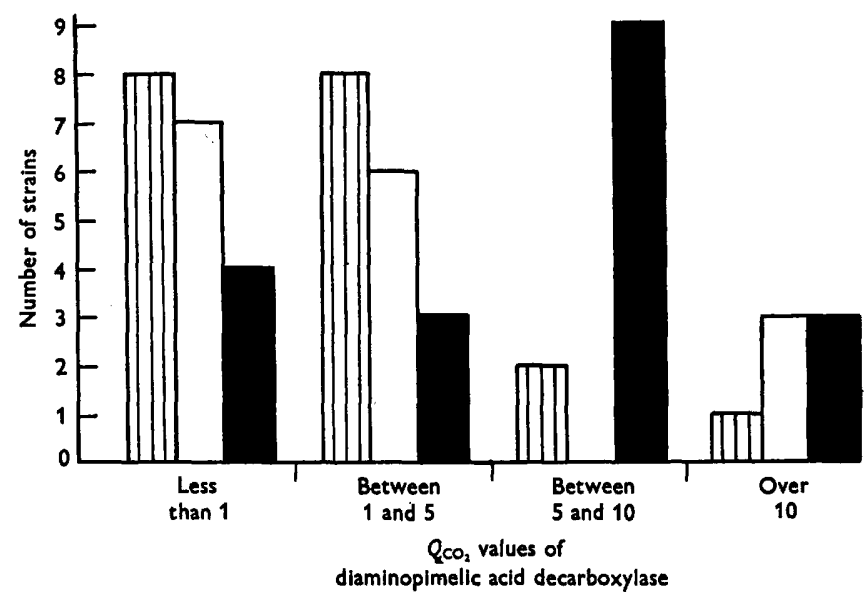

Fig. 1. The distribution of diaminopimelic acid decarboxylase activity: Escherichia coli types 1 and 2, striped columns; intermediate types, white columns; Aerobacter aerogenes type 1, shaded columns.

\section{DISCUSSION}

In this survey enzyme activity was estimated in organisms grown and tested under standard conditions. It was impracticable to find the effect of growth time and temperature on the enzyme activity of each organism, nor could the enzyme always be tested at its optimal $\mathrm{pH}$. The phase of growth at harvesting has been found to be very critical with one strain of Escherichia coli but not with Aerobacter aerogenes (Dewey et al. 1954), while the $\mathrm{pH}$ optima for the enzyme from the two organisms differed by $0 \cdot 4$ units. The $\mathrm{pH}$ value $6 \cdot 8$ was chosen as a compromise between the optimum for the diaminopimelic acid and lysine decarboxylases, and the $\mathrm{CO}_{2}$ retention by the buffer. The $\mathbf{Q}_{\mathrm{CO}_{2}}$ values are thus not a true measure of diaminopimelic acid decarboxylase activity but are only relative and can only be compared when all the cells are tested at the same $\mathrm{pH}$. The Warburg manometer was not sufficiently sensitive to detect very small amounts of enzyme; from the large number of strains found to contain only a trace, it seems probable that many of the strains recorded as 'negative' may contain traces of diaminopimelic acid decarboxylase below the limit of sensitivity of the test.

Cell-free extracts containing diaminopimelic acid decarboxylase are activated by pyridoxal phosphate (Dewey et al. 1954). As the complete acetone-dried cells were present in the Warburg cups, no additional pyridoxal phosphate was added. It is unlikely that the absence of enzyme activity could have been due to lack of co-enzyme rather than lack of the enzyme 


\section{Distribution of diaminopimelic acid decarboxylase}

itself, since the organisms used are known to synthesize their own pyridoxal requirements.

There was no correlation between amount of enzyme and the amount of diaminopimelic acid in the corresponding cell hydrolysates. Diaminopimelic acid has been found in several organisms in which no decarboxylase could be detected, and two Gram-positive cocci which contained no diaminopimelic acid have been shown (Dewey, Hoare \& Work, 1953) to contain diaminopimelic acid decarboxylase.

Davis (1952) suggested that diaminopimelic acid is an intermediate in the synthesis of lysine in Escherichia coli ATCC 9637. It seems unlikely that the strains which contain little or no diaminopimelic acid decarboxylase can derive all their lysine requirements from diaminopimelic acid. Roberts $e$ al . (1953) reported that in another strain of $E$. coli, lysine was formed by a pathway not involving diaminopimelic acid. Evidence that diaminopimelic acid decarboxylase is active in normal cells of $E$. coli ATCC 9637 is shown by the fact that diaminopimelic acid accumulates in the culture medium of certain mutants which require lysine but which lack diaminopimelic acid decarboxylase (Dewey \& Work, 1952 $a$; Davis, 1952). The presence of an enzyme in acetone-dried cells is no proof that the enzyme is actually used by the growing cell, and further work is required before a metabolic role may be assigned to diaminopimelic acid decarboxylase.

Of 58 organisms of the coli-aerogenes group tested, $48(83 \%)$ contained detectable diaminopimelic acid decarboxylase activity. Gale (1946) reported that out of 151 strains of Escherichia coli tested $94 \%$ contained lysine decarboxylase. That no strain has yet been found to contain diaminopimelic acid decarboxylase but not lysine decarboxylase seems probably due to the wide distribution of the latter enzyme in these organisms.

I wish to thank Dr E. F. Gale, Mr H. Proom and Prof. Wilson Smith for cultures, Dr Elizabeth Work for advice and guidance and Mr R. Boardman for technical assistance. I also wish to acknowledge a maintenance grant from the Rockefeller research fund of this Medical School.

\section{REFERENCES}

The Bacteriological Examination of Water Supplies (1939). Rep. publ. Hlth. med. Subj., Lond. no. 71.

Davis, B. D. (1952). Diaminopimelic acid and lysine. Biosynthetic inter-relations of lysine, diaminopimelic acid and threonine in mutants of Escherichia coli. Nature, Lond. 169, 534.

Dewey, D. L. \& Wallace, P. R. E. (1953). An automatic inoculating machine. Sci. Tech. Ass. Bull. 3, 5.

Dewey, D. L. \& Work, E. (1952a). Diaminopimelic acid and lysine. Diaminopimelic acid decarboxylase. Nature, Lond. 169, 533.

Dewey, D. L. \& Work, E. (1952b). Diaminopimelic acid decarboxylase in bacteria. 2nd Int. Congr. Biochem. p. 77.

Dewey, D. L., HoARe, D. S. \& Work, E. (1953). Decarboxylation of diaminopimelic acid and its relation to lysine biosynthesis in bacteria. Proc. 6th Int. Congr. Microbiol. 1, 129. 
Dewey, D. L., HoAre, D. S. \& Work, E. (1954). Diaminopimelic acid decarboxylase 1. Properties in cells and cell-free extracts of Escherichia coli and Aerobacter aerogenes. Biochem. J. (in the Press).

GaLe, E. F. (1946). The bacterial amino acid decarboxylases. Advanc. Enzymol. 6, 1. Proom, H. \& Worwod, A. J. (1951). The distribution of glutamic acid decarboxylase in the family Enterobacteriaceae examined by a simple chromatographic method. J. gen. Microbiol. 5, 681.

Roberts, R. B., Cowie, D. B., Britten, R., Bolton, E. \& Abelson, P. H. (1953). The role of the tricarboxylic acid cycle in amino acid synthesis; and the synthesis of the aspartic and glutamic families of amino acids in Escherichia coli. Proc. Nat. Acad. Sci., Wash. 39, 1013, 1020.

Work, E. (1951). The isolation of $\alpha$ - $\epsilon$-diaminopimelic acid from Corynebacterium diphtheria and Mycobacterium tuberculosis. Biochem. J. 49, 17.

Work, E. \& Dewey, D. L. (1953). The distributions of $\alpha-\varepsilon$-diaminopimelic acid among various micro-organisms. J. gen. Microbiol. 9, 394.

(Received 14 May 1954) 